\title{
Average Monthly and Annual Rainfall Distribution in Puerto Rico'
}

\author{
Eliodoro J. Ravalo, Megh R. Goyal and Carlos R. Almodóvar ${ }^{2}$ \\ ABSTRACT \\ Average annual and monthly rainfall distribution in Puerto Rico are pre- \\ sented in isohyetal charts which indicate that January, February, March, July \\ and December belong to the dry season. The southern coast of Puerto Rico \\ receives the least rainfall compared to that of the southern and northern \\ slopes, north coast, eastern and western interiors, respectively.
}

\section{INTRODUCTION}

Rainfall data is of particular interest to those concerned with the effective use of soil and water (5). The weather is often the controlling factor in problems of preventing excessive soil movement, retaining needed moisture, increasing the intake of surface water, adding needed water by irrigation, and removing excess water by drainage. Moisture, whether too much, too little, or poorly distributed, is one of the major limitations in agricultural production. It is essential to know rainfall distribution patterns at a location for a good water management project. Monthly and annual rainfall amount over a watershed can be computed from isohyetal charts, which are similar to topographic maps. Isohyetal lines indicate equal rainfall $(4,5)$. Capiel and Calvesbert (1) summarized agricultural water balance of Puerto Rico.

This study presents annual and monthly isohyetal charts (January through December) for Puerto Rico.

\section{MATERIALS AND METHODS}

Available rainfall data (3) and publication No. 11-45 of the Weather Bureau, US Department of Commerce (2) were used to calculate the average rainfall corresponding to each weather station identified in table 1. Lines of equal rainfall (isohyets) were interpolated with calculated amounts at weather stations. These isohyets are plotted in figures 1 to 13.

\section{RESULTS AND DISCUSSION}

Annual and monthly average rainfall distribution are shown in isohyetal charts 1 to 13. In these graphs, Adjuntas, Gurabo substations; Corozal,

'Manuscript submitted to Editorial Board February 24, 1986. This information has been collected and analyzed under projects C 411, "Bioclimate of Puerto Rico" and CBAG-PR23, "Irrigation requirement estimations in Puerto Rico".

${ }^{2}$ Associate Agricultural Engineers and Research Assistant, Agricultural Experiment Station, University of Puerto Rico, Mayagüez Campus, Río Piedras, P.R. 
RAVAIO ET AL., RAINFALL

TABLE 1.--Weather station index and location (2)

\begin{tabular}{|c|c|c|c|c|c|c|}
\hline \multicolumn{2}{|r|}{ Stalion } & \multirow{2}{*}{ County $^{2}$} & \multirow{2}{*}{$\begin{array}{c}\text { Index } \\
\text { number }\end{array}$} & \multirow{2}{*}{ Latitude $N$} & \multirow{2}{*}{ Longitude $W$} & \multirow{2}{*}{ Elevation ${ }^{4}$} \\
\hline No. ${ }^{\prime}$ & Iocation & & & & & \\
\hline & & & & $\cdot$ & $\circ \quad 1$ & $m$ \\
\hline 1 & Aceituna & Villalba & 0040 & 1809 & 6629 & 652.5 \\
\hline $2^{6}$ & Adjuntas & Ponce & 0061 & 1811 & 6648 & 450.0 \\
\hline 3 & Aguirre & Guayama & 0147 & 1758 & 6613 & 15.0 \\
\hline 4 & Aibonito & Guayama & 0158 & 1808 & 6616 & 690.0 \\
\hline 5 & Arecibo $2 \mathrm{ESE}$ & Arecibo & 0410 & 1828 & 6642 & 4.5 \\
\hline 6 & Barceloneta 2 NNW & Arecibo & 0662 & 1829 & 6632 & 22.8 \\
\hline 7 & Barranquitas & Guayama & 0736 & 1811 & 6619 & 540.0 \\
\hline 8 & Bayamon Hato Tejas & San Juan & 0842 & 1825 & $66 \quad 12$ & 54.0 \\
\hline 9 & Cabo Rojo & Mayagüez & 1123 & 1805 & 6709 & 75.0 \\
\hline 10 & Caguas & Guayama & 1300 & 1814 & 6602 & 75.0 \\
\hline 11 & Calero Camp & Agundilla & 1345 & 1829 & 6707 & 73.8 \\
\hline 12 & Canóvanas $2 \mathrm{~N}$ & Humacao & 1590 & 1824 & 6505 & 9.0 \\
\hline 13 & Caonillas Utuado & Arecibo & 1623 & 1816 & 6639 & 255.0 \\
\hline 14 & Caonillas Villalba & Ponce & 1634 & 1807 & $66 \quad 29$ & 180.0 \\
\hline 15 & Carile Camp Tunnel & Guayama & 1701 & 1804 & 6606 & 600.0 \\
\hline 16 & Carite Plant 1 & Guayama & 1712 & 1803 & 6606 & 288.0 \\
\hline 17 & Cataño & San Juan & 1845 & 1825 & 6607 & 6.0 \\
\hline 18 & Cayey $1 \mathrm{NW}$ & Guayama & 1901 & 1807 & 6609 & 420.0 \\
\hline 19 & Central San Franciseo & Mayagüez & 2316 & 1759 & 6848 & 9.0 \\
\hline 20 & Cidra $3 \mathrm{E}$ & Guayama & 2634 & 1811 & 6608 & 420,0 \\
\hline 21 & Coamo Dam & Ponce & 2723 & 1801 & 6023 & 55.5 \\
\hline 22 & Coloso & Aguadilla & 2801 & 1823 & 6709 & 15.0 \\
\hline 23 & Comerio Falls & Guayama & 2823 & 1816 & 6611 & 150.0 \\
\hline $24^{5}$ & Corozal $4 \mathrm{~W}$ & San Juan & 2934 & 1820 & 6622 & 120.0 \\
\hline 25 & Dorado $4 \mathrm{~W}$ & Arecibo & 3409 & 1828 & 6617 & 7.5 \\
\hline 27 & Dos Bocas & Arecibo & 3431 & 1820 & 6640 & 60.0 \\
\hline 28 & Ensenada & Mayagüez & 3532 & 1758 & 6855 & 7.5 \\
\hline 29 & Fajardo & Humacao & 3657 & 1820 & 6539 & 12.0 \\
\hline 30 & Garzas Danı & Ponce & 3871 & 1808 & 6644 & 745.5 \\
\hline 31 & Guajataca Dam & Aguadilla & 3904 & 1824 & 6656 & 196.8 \\
\hline 32 & Guayabal Reservoir & Ponce & 4126 & 1806 & 6830 & 81.0 \\
\hline 33 & Guayama & Guayama & 4193 & 1759 & 6607 & 58.5 \\
\hline 34 & Guayanil]a & Mayagüez & 4211 & 1800 & 6652 & 9.0 \\
\hline $36^{6}$ & Gurabo & Humacao & 4276 & 1815 & 6600 & 48.0 \\
\hline 37 & Humacao I SW & Humacao & 4613 & 1808 & 6550 & 30.0 \\
\hline 38 & Indiera Baja & Aguadilla & 4685 & 1811 & 6654 & 840.0 \\
\hline $39^{6}$ & Isabela $4 \mathrm{SW}$ & Aguadilla & 4702 & 1828 & 6704 & 126.0 \\
\hline 40 & Jájome Alto & Guayama & 4867 & 1805 & 6608 & 715.5 \\
\hline 41 & Jayuya & Ponce & 4910 & 1813 & 6635 & 420.0 \\
\hline 43 & Juana Diaz Camp & Ponce & 5020 & 1803 & 6630 & 60.0 \\
\hline \multirow[t]{2}{*}{44} & $\mathrm{Juncos} 1 \mathrm{E}$ & Humacao & 5064 & 1814 & 6553 & 81.0 \\
\hline & La FE: & Humacao & 5075 & 1814 & 6546 & 45.0 \\
\hline
\end{tabular}


TABLE 1.-Continued

\begin{tabular}{|c|c|c|c|c|c|c|}
\hline \multicolumn{2}{|r|}{ Station } & \multirow{2}{*}{ County ${ }^{2}$} & \multirow{2}{*}{$\begin{array}{l}\text { Index } \\
\text { number }\end{array}$} & \multirow{2}{*}{ Lutitude $\mathrm{N}$} & \multirow{2}{*}{ Longitude $\mathrm{W}$} & \multirow{2}{*}{ Elevation ${ }^{4}$} \\
\hline No. ${ }^{1}$ & Location & & & & & \\
\hline $45^{i}$ & Lajas & Mayagüez & 5097 & 1802 & 6705 & 30.0 \\
\hline 47 & Lares & Aguadilla & 5175 & 1817 & 6653 & 360.0 \\
\hline 48 & Manati & Arecibo & 5807 & 1826 & 6627 & 75.0 \\
\hline 50 & Maricao & Aguadilla & 5908 & 1809 & 6659 & 450.0 \\
\hline 51 & Maricao Fish Hatchery & Aguadilla & 5911 & 1810 & 6659 & 450.0 \\
\hline 52 & Matrullas Dam & Ponce & 6017 & 1812 & 6628 & 750.0 \\
\hline 53 & Maunabo $1 \mathrm{SW}$ & Guayama & 6050 & 1800 & 6554 & 15.0 \\
\hline $54^{5}$ & Mayagüez & Mayagüez & 6073 & 1813 & 6708 & 24.0 \\
\hline 57 & Mora Camp & Aguadilla & 6361 & 1828 & 6702 & 123.0 \\
\hline 58 & Naguabo $6 \mathrm{~W}$ & Humacas & 6432 & 1814 & 6544 & 30.0 \\
\hline 59 & Paraiso & Humacao & 6805 & 1818 & 6542 & 45.0 \\
\hline 60 & Patillas Dam & Guayama & 6904 & 1802 & 6602 & 72.0 \\
\hline 61 & Peniuelas Salto Garzas & Mayagüez & 6982 & 1805 & 6644 & 345.9 \\
\hline $62^{5}$ & Ponce $4 \mathrm{E}$ & Ponce & 7292 & 1801 & 6632 & 12.0 \\
\hline 64 & Puerto Real & Mayagüez & 7492 & 1806 & 6711 & 4.5 \\
\hline 65 & Quebradillas & Aguadilla & 7843 & 1828 & 6656 & 111.6 \\
\hline 66 & Ramey Air Force Base & Aguadilla & 7898 & 1830 & 6708 & 71.1 \\
\hline 67 & Río Blanco Lower & Humacao & 8144 & 1815 & 6547 & 39.0 \\
\hline 68 & Río Blanco Upper & Humacao & 8155 & 1817 & 8547 & 432.0 \\
\hline $71^{5}$ & Rio Piedras & San Juan & 8301 & 1824 & 6604 & 30.0 \\
\hline 75 & San Germán & Mayagüez & 8757 & 1805 & 6703 & 114.0 \\
\hline 76 & San Juan W B City & San Juan & 8808 & 1828 & 6606 & 14.1 \\
\hline 77 & $\begin{array}{l}\text { San Juan (airport) WB } \\
\quad \text { AP } 2\end{array}$ & San Juan & 8812 & 1826 & 6600 & 4.5 \\
\hline 78 & San Lorenzo Espino & Humacao & 8817 & 1806 & 6600 & 381.0 \\
\hline 79 & San Sebastián & Aguadilla & 8881 & 1821 & 6701 & 67.5 \\
\hline 80 & Santa Isabel $3 \mathrm{NW}$ & Ponce & 8940 & 1800 & 6626 & 8.4 \\
\hline 81 & Santa Rita & Mayegüez & 8955 & 1802 & 6652 & 52.5 \\
\hline 82 & Toa Baja Constancia & San Juan & 9421 & 1826 & 6615 & 15.0 \\
\hline 83 & 'Toro Negro Plant 2 & Ponce & 9466 & 1810 & 6631 & 675.0 \\
\hline 84 & Utuado & Arecibo & 9608 & 1816 & 6642 & 129.0 \\
\hline 85 & Villalba & Ponce & 9774 & 1808 & 6629 & 156.0 \\
\hline 87 & Yabucoa 1 NNE & Humacao & 9829 & 1804 & 6552 & 30.0 \\
\hline 88 & Yauco lS & Mayagüez & 9862 & 1801 & 6651 & 7.5 \\
\hline
\end{tabular}

${ }^{1}$ Weather Stations around the island of Puerto Rico are identified by these numbers in rainfall distribution charts (figures 1 to 13 ).

${ }^{2}$ As of 1950.

${ }^{3}$ Identification numbers are assigned by the Weather Bureau on a state basis and are not reassigned in the future to their stations.

${ }^{4}$ Elevation of weather station above sea level, meters.

5 These weather stations are located at Agricultural Research Centers of UPR-RUM. 


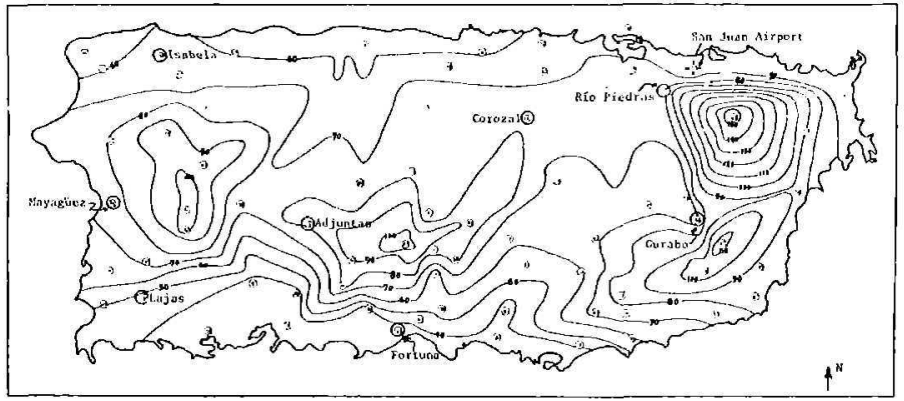

Fig. 1.-Annual isohyetal chart of Puerto Rico. Each value of the contour indicates average rainfall amount in inches which should be multiplied by 2.54 to convert into centimeters. Circled numbers refer to weather stations, which are identified in table 1.

(2) Adjuntas Substation

(24) Corozal Substation

(36) Gurabo Substation

(39) Isabela Substation

(77) San Juan Airport
(45) Lajas Substation

(54) UPR-RUM Mayagüez

(62) Fortuna Substation

(71) Agric. Exp. Station, Río Piedras

(1) Weather stations

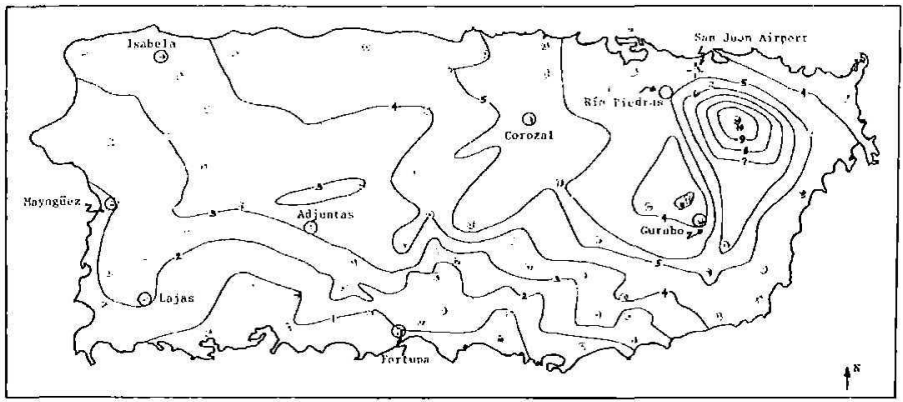

FIG. 2.-Monthly isohyetal chart (inches) of Puerto Rico for January.

Fortuna and Isabela, Lajas, Mayagüez, Río Piedras Agricultural Research and Development Centers, and San Juan Airport are identified by circled numbers $2,36,24,62,39,45,54,71$ and 77 , respectively. Contour values in all graphs are in inches. 


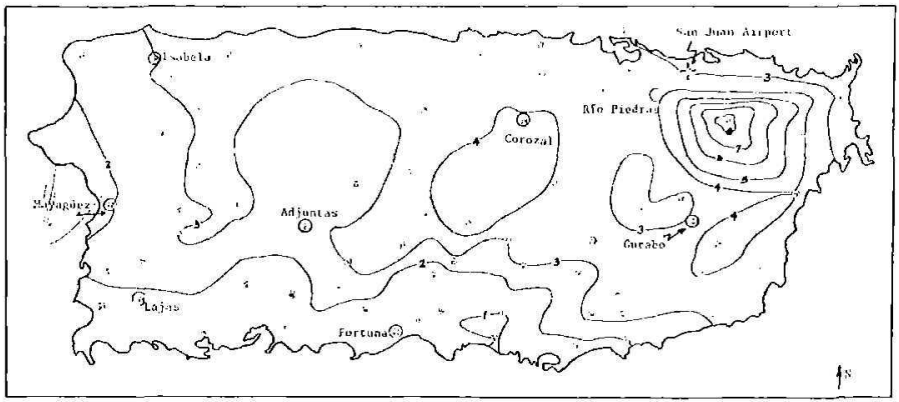

Fig. 3.-Monthly isohyetal chart (inches) of Puerto Rico for February.

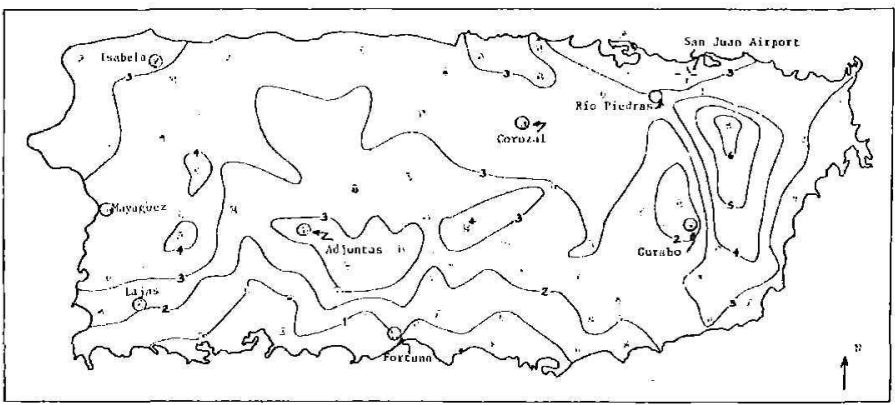

Fıc. 4.-Monthly isohyetal chart (inches) of Puerto Rico for March.

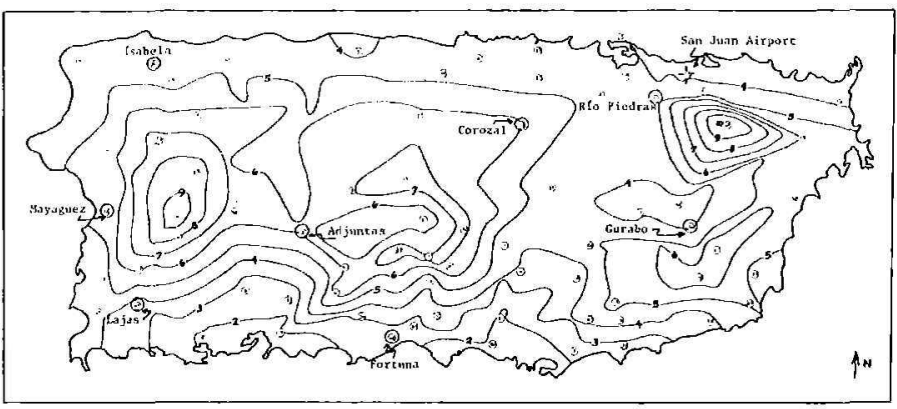

FiG. 5. - Monthly isohyetal chart (inches) of Puerto Rico for April. 


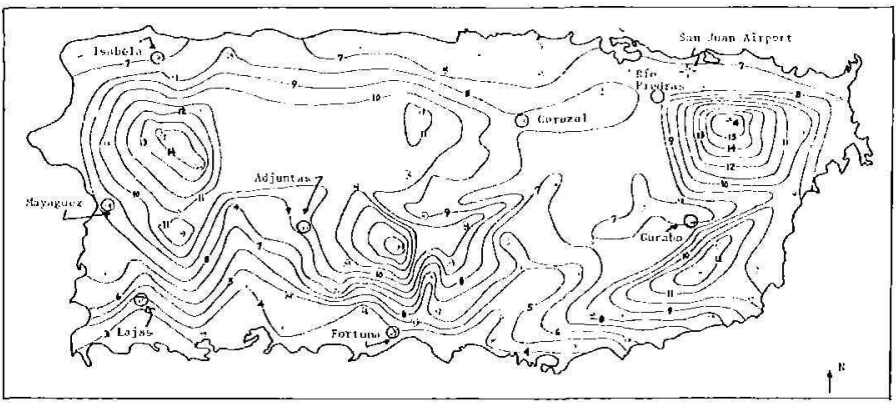

Fic. 6.-Monthiy isohyetal chart (inches) of Puerto Rico for May.

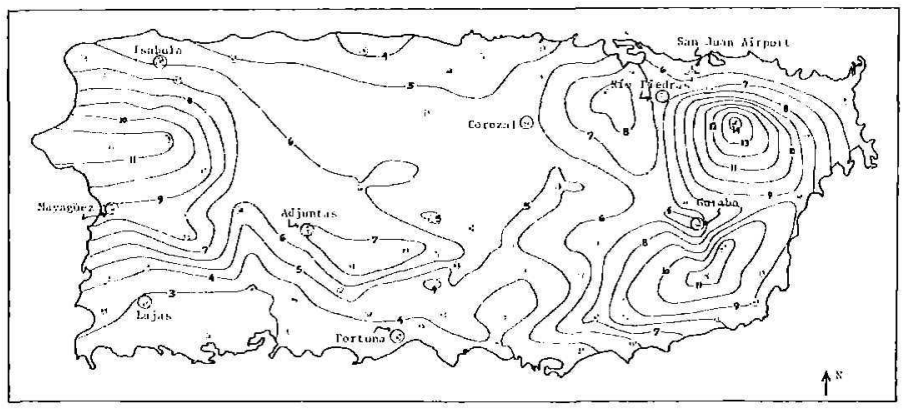

FIG. 7.-Monthly isohyetal chart (inches) of Puerto Rico for June.

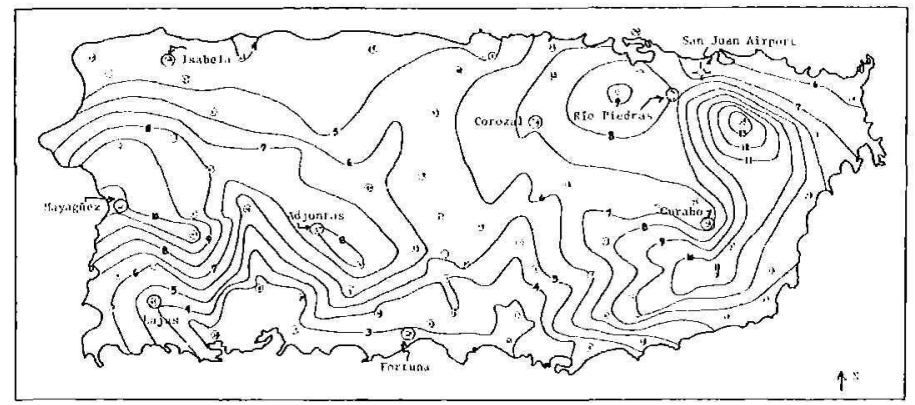

FIG. 8.-Monthly isohyetal chart (inches) of Puerto Rico for July. 


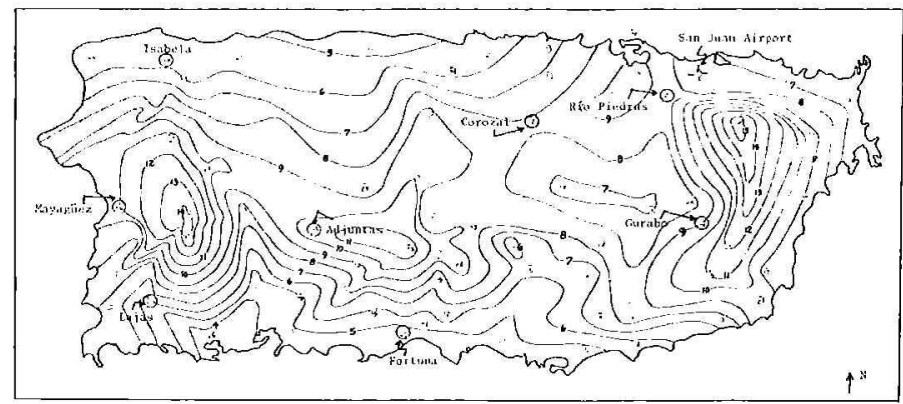

FIc, 9.-Monthly isohyetal chart (inches) of Puerto Rico for August.

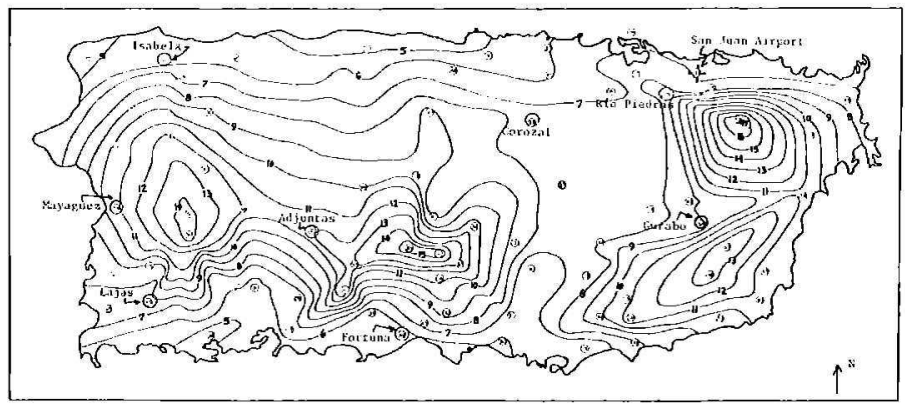

Fig. 10.-Monthly isohyetal chart (inches) of Puerto Rico for September.

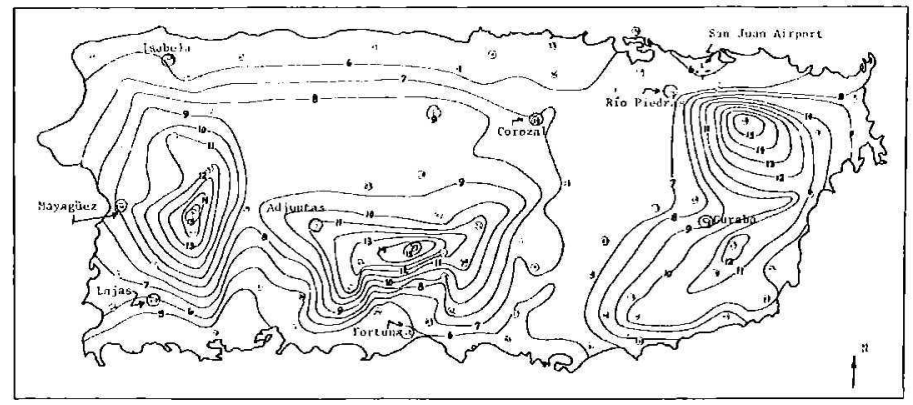

FIc. 11.--Monthly isohyetal chart (inches) of Puerto Rico for Oetober. 


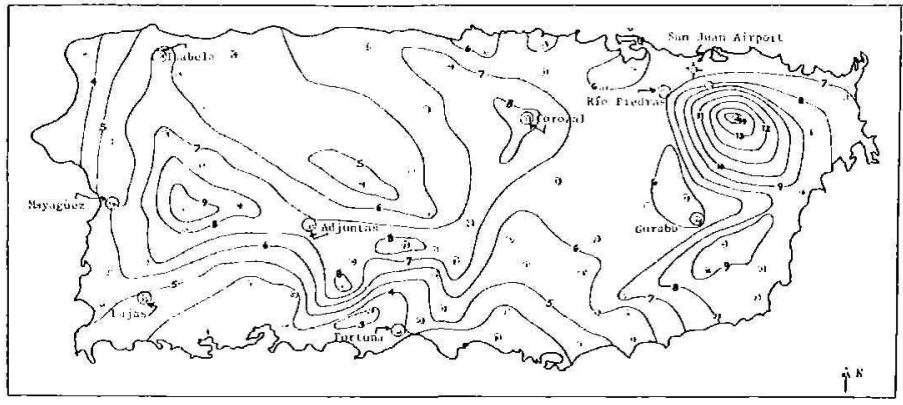

Fic. 12,-Monthly isohyetal chart (inches) of Puerto Rico for November.

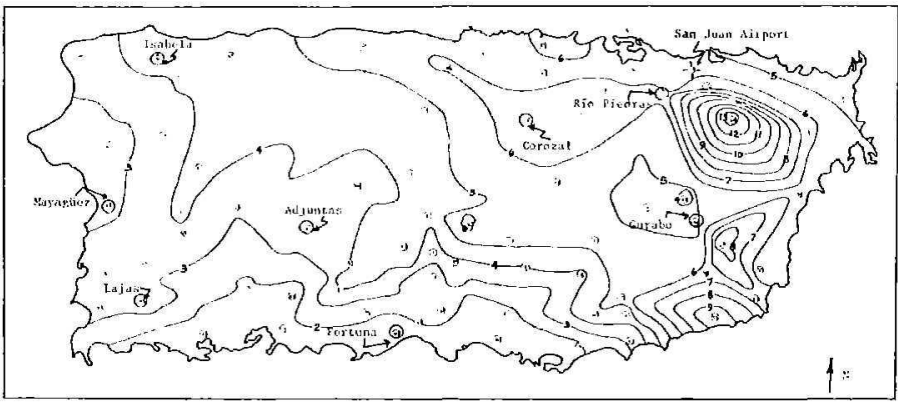

FIc. 13.-Monthly isohyetal chart (inches) of Puerto Rico for December.

Figure 1 indicates that the south coast of Puerto Rico receives annual average rainfall of less than $102 \mathrm{~cm}$ compared to that of 102 to $178 \mathrm{~cm}$ in the southern slopes; 178 to 254 in the western interior; 178 to 382 in the eastern interior; 152 to 178 in the northern slopes; and less than 165 $\mathrm{cm}$ in the north coast of Puerto Rico, respectively. Figures 2 to 4 reveal that the south coast receives 2.5 to $5.0 \mathrm{~cm}$ of rainfall during January/ February or March compared to $25 \mathrm{~cm}$ in the E1 Yunque rain forest. April to November are wetter months as shown in figures 5 to 12 than December through March (figures $13,2,3,4)$ respectively. It is not unusual to have from 1 to 2 tropical storms from August to November.

Average depth of rainfall for any given location can be interpolated or extrapolated from figures 1 to 13. The following example shows how to calculate average annual rainfall at the Lajas Agricultural Research and Development Center (Weather Station \#45). 
Example: The Lajas Research Center is located between isohyets 40 and 50 (fig. 1): Assume a least distance of $X_{1}$ between contour 50 and the weather station; and a least distance of $X_{2}$ between contour 40 and the weather station. Then, average depth of rainfall (inches) at the weather station $=\left(50 \mathrm{X}_{1}+40 \mathrm{X}_{2}\right) /\left(\mathrm{X}_{1}+\mathrm{X}_{2}\right)$.

\section{RESUMEN}

Se prepararon cartas isopluviales para ilustrar la distribución media de precipitación anual y mensual en Puerto Rico. Las cartas indican que enero, febrero, marzo, julio y diciembre pertenecen a la estación seca. La costa sur de Puerto Rico recibe menos precipitación comparada con la de las vertientes sur y norte, la costa norte y los interiores este y oeste, respectivamente.

\section{LITERATURE CITED}

1. Capiel, M. and R. J. Calvesbert, 1976. On the climate of Puerto Rico and its agricultural water balance. J. Agric. Univ P.R., 60 (2): 139-53.

2. Climatography of the United States No. 11-45 of Puerto Rico and US Virgin Islands. In: Climatic Summary of the US-Supplement for 1931 through 1952. US Department of Commerce, Washington, D.C.

3. Hourly precipitation data: Puerto Rico and Virgin Islands, updated 1984. National Climatic Data Center, Asheville, NG 28801.

4. Kirpich, P.Z., 1952. Hydrology In: Handbook of Applied Hydraulics by C. V. Davis, McGraw-Hill Book Co., Inc, 2nd ed, pp. 1159-77.

5. Schwah, G. O., R. K. Frevert, T. W. Edminster and K. K. Barnes, 1981. Precipitation, Chapter 2 In: Soil and Water Conservation Engineering, 3rd ed, John Wiley \& Sons, New York. Pages 17-48. 